\title{
Occurrence of Sclerotinia Foliage Blight Disease of Cucumber and Pepper Plants under Protected Cultivation System in Egypt II. Bio-Control Measures against Sclerotinia Spp. in Vitro
}

\author{
M. M. Abdel-Kader ${ }^{*}$, N. S. El-Mougy, M. D. E. Aly, E. I. Embaby \\ Plant Pathology Department, National Research Centre, Giza, 12622, Egypt
}

\begin{abstract}
Severe outbreaks of stem or fruit rot symptoms with sclerotial formation were observed as first occurrence during a disease survey of cucumber and pepper crops during the cool season, 2011 in the Protected Cultivation Station, Ministry of Agriculture located at Tookh province, Qalubiya governorate, Egypt. This disease appears during the growing season at the seedling or mature stages of plant growth. Recently, interest has been shown in combining microbial biocontrol agents with other chemical components to increase their activity against plant pathogens. To reach the proposed aim determination of the efficacy of some plant-derived essential oils, plant resistance inducers and plant extracts in combination with biocontrol agents against the growth of Sclerotinia foliage blight pathogens $S$. sclerotiorum and $S$. minor was carried out under in vitro conditions. The obtained results in the present study has shown the potential of tested materials as effective inhibitors against pathogenic fungi when combined factors with antagonistic bioagents.
\end{abstract}

Keywords Antagonism, Bacillus subtilis, Essential Oils, Plant Resistance Inducers, Pseudomonas fluorescens, T. harzianum, T. Viride, Sclerotinia Foliage Blight, S. sclerotiorum, S. Minor

\section{Introduction}

Cucumber and pepper are of paramount importance in the Egyptian diet. They are considered among the most important vegetable, being cultivated either in plastic houses or open field. Vegetables are attacked by certain soilborne fungi. The soil-borne plant pathogens Sclerotinia minor and Sclerotinia sclerotiorum cause severe economic losses of many vegetable and ornamental crops around the world. Severe outbreaks of stem or fruit rot symptoms with sclerotial formation were observed as first occurrence during a disease survey of cucumber and pepper crops during the cool season, 2011 in the Protected Cultivation Station, Ministry of Agriculture located at Tookh province, Qalubiya governorate, Egypt $[1,2]$. The management strategy followed by the farmers included an unwise, intensive use of fungicides. This strategy was not a satisfactory solution for controlling Sclerotinia disease. Recently, interest has been shown in combining microbial biocontrol agents with other chemical The increasing interest in pesticide alternatives was due to

* Corresponding author:

mokh_nrc@yahoo.com (M.M. Abdel-Kader)

Published online at http://journal.sapub.org/als

Copyright (C) 2011 Scientific \& Academic Publishing. All Rights Reserved the toxicity implication of pesticides for humans. Therefore, there will be an increasingly driven demand motivated by different priorities such as health benefits, cost, ecological benefits, ethical issues, food safety and sustainability of supply.

Biological control approach depends upon the establishment and maintenance of a threshold population of introduced bioagent into the soil, and a drop in viability below that level may eliminate the possibility of biological control. Many soil edaphic factors, including temperature, moisture, $\mathrm{pH}$ and nutrition influence the survival and establishment of the bioagent and their interaction with the pathogens. Plant products are characterized as having a wide range of volatile compounds could be used as alternative anti-bacterial and anti-fungal treatments[3].

On the other hand, many investigations reported the use of potassium salts $\left(\mathrm{K}_{2} \mathrm{HPO}_{4}\right.$ or $\left.\mathrm{KNO}_{3}\right)$ as a chemical agent for induction of plant resistance [4, 5]. Furthermore, Humic and Fulvic acids have been early recorded to have appositive effect against plant pathogens and their cells biological activities $[6,7,8,9]$.

Against this background and the demand for natural products as raw material for new antifungal agents, the objective of the present work was aimed to get a suitable formula could be used for controlling such diseases. To reach 
the proposed aim determination of the efficacy of some plant-derived essential oils, plant resistance inducers and plant extracts in combination with biocontrol agents against the growth of Sclerotinia foliage blight pathogens S. sclerotiorum and $S$. minor was carried out under in vitro conditions.

\section{Material and Methods}

\subsection{Pathogens and Antagonists}

Virulent pathogenic fungal isolates of S. sclerotiorum and S. minor isolated from cucumber and pepper plants infected with Sclerotinia foliage blights diseases[1,2]. Antagonistic microorganisms, i.e. Trichoderma harzianum, T. viride, Bacillus subtilis, Pseudomonas fluorescens were obtained from the Plant Pathology Department of the National Research Centre, Giza, Egypt. These antagonistic microorganisms were isolated from the rhizosphere of various healthy and root rot infected leguminous crops, grown in the Delta and Middle Egypt regions, and proved their high pathogenic or antagonistic ability during previous work at the same department. Fungal and bacterial cultures were maintained on potato dextrose agar (PDA) and nutrient agar slant media at $5 \pm 1^{\circ} \mathrm{C}$ as stock cultures until use. All isolates were refreshed by growing at the optimum growth conditions at the beginning of the present experiments.

\subsection{Growth Media}

PDA and nutrient broth medium (Difco Laboratories, Detroit, MI) were used for growing fungal and bacterial isolates tested in the present work.

\subsection{In Vitro Antagonism Studies}

The inhibitory effect of the abovementioned fungal and bacterial antagonistic agents against the linear growth of $S$. sclerotiorum and S. minor pathogenic fungi was evaluated using the modified dual culture technique[10].

Abundant fungal and bacterial growth was first prepared. Ten $\mathrm{mL}$ of each individual bacterial isolate was grown for $48 \mathrm{~h}$ on nutrient broth medium and poured into flasks containing sterilized PDA medium. Before solidifying, each flask was rotated gently to ensure equal distribution of bacterial growth, and then poured into 9-cm-diameter Petri dishes. Inoculated plates were incubated for $48 \mathrm{~h}$ at $25^{\circ} \mathrm{C}$.

For fungal growth, a 5-mm disk of each tested fungi was transferred to the centre of a PDA plate then incubated at $25^{\circ} \mathrm{C}$. The incubation period was 7 days for antagonistic and pathogenic fungi.

In vitro antagonistic studies of biocontrol microorganisms and pathogenic fungi were performed on PDA medium in 9-cm-diameter Petri dishes. A 5-mm disk of each antagonistic fungal or bacterial growth culture was placed onto the PDA (amended with tested target), $10 \mathrm{~mm}$ from the edge of the Petri dish. Another disk of the same diameter of each pathogenic fungal growth culture was placed on the opposite side of the dish at the same distance. The control treatment was inoculated with a culture disk of either a pathogenic or antagonistic culture alone at the same conditions. Both experimental and control dishes were assigned to a completely randomized design, with five replicates per treatment. All inoculated Petri dishes were incubated at $25 \pm 1^{\circ} \mathrm{C}$ and the fungal growth diameter away from and towards the antagonist agent was measured after the pathogenic fungal growth in the control treatment had reached the edge of the Petri dish. This test was repeated three times and the inhibition was calculated as the percentage reduction in colony diameter growth compared with the control.

\subsection{Effect of Essential Oils on Antagonistic Ability}

Three essential oils at concentrations of $0.25,0.5$, and $1.0 \%$ were evaluated for their effect on the antagonistic ability of tested microorganisms against $S$. sclerotiorum and $S$. minor fungal radial growth, through in vitro tests.

Pure-grade of the essential oils, i.e. cinnamon (Cinnamomum verum L.), clove (Syzygium aromaticum L.) and thyme (Thymus vulgaris L.) were obtained from Cairo Company for oils and aromatic extractions CID (Cairo Industries Development), Egypt. The essential oils were stored in dark glass bottles.

Emulsified stocks at high concentrations of tested essential oils were prepared by dissolving in sterilized distilled water. A few drops of the emulsifier Tween 20 (Sigma Co.) were added to the essential oil volumes to obtain an emulsion feature. Different volumes of the essential oil emulsion were added to conical flasks containing $100 \mathrm{ml}$ of sterilized PDA medium before its solidification, to obtain the proposed concentrations. The supplemented media were poured into Petri-dishes $(9 \mathrm{~cm})$ about $20 \mathrm{ml}$ each. The control check treatment was PDA medium which was free of essential oils. The in vitro antagonistic ability of tested microorganisms was preformed following the method described by Ferreira $e t$ al. (1991) as abovementioned procedures.

\subsection{Effect of Plant Resistance Inducers on Antagonistic Ability}

The effect of the chemical plant inducers on the antagonistic ability of different microorganisms against the growth of the $S$. sclerotiorum and S. minor fungi was evaluated in vitro. The tested antagonistic microorganisms were T. harzianum, $T$. viride, B. subtilis and P. fluorescens The tested chemical inducers were Sodium bicarbonate and Potassium bicarbonate, Calcium chloride and potassium mono -hydrogen phosphate (at concentrations of 1.0, 2.0 and 4.0\%, $\mathrm{v} / \mathrm{v}$ ), humic and folic acids (mixture,1:1) at concentrations of $0.2,0.4$ and $0.6 \%,(\mathrm{v} / \mathrm{v})$. The plant inducers were added individually to conical flasks containing sterilized PDA before its solidifying to obtain the proposed concentrations. Twenty $\mathrm{ml}$ of amended media were poured into $9 \mathrm{~cm}$ diameter Petri dishes, and another set of untreated PDA plates was used as control. The antagonistic ability of tested microorganisms was preformed following the method de- 
scribed by Ferreira et al. (1991) as abovementioned procedures.

\subsection{Effect of Plant Extracts on Antagonistic Ability}

Extracts of three plant leaves, i.e. Halfa Bar (Cymbopogon Proximus); Ginger (Zingiber officinale) and Bay laurel (Laurus nobilis) were evaluated for their inhibitory effect on fungal linear growth using in vitro test. The plant materials kindly obtained from Medicinal and Aromatic Plants Research Department, NRC, Egypt. The materials were washed with distilled water and dried in shade. The dried plant materials were then finely grinded to powder. Fifty grams of each plant material in powder form was homogenized by laboratory blender in $200 \mathrm{ml}$ of ethanol $(96 \%)$ and distilled water $(20: 80, \mathrm{v}: \mathrm{v})$ for $10 \mathrm{~min}$, then left in dark glass bottles for $72 \mathrm{~h}$ for tissue maceration. The extracts were filtered through thin cheesecloth sheets. The final extracts were collected separately in other dark glass bottles and exposed to $60^{\circ} \mathrm{C}$ in water bath for $30 \mathrm{~min}$ for ethanol evaporation. The collected extracts were then stored in a refrigerator at $5^{\circ} \mathrm{C}$ until needed. The extracts were added to sterilized PDA flasks before solidifying to obtain the proposed concentrations of 1,2 and $4 \%(\mathrm{v} / \mathrm{v})$. The supplemented media were poured into Petri-dishes $(9 \mathrm{~cm})$ about $20 \mathrm{ml}$ each. The control check treatment was PDA medium which was free of essential oils. The in vitro antagonistic ability of tested microorganisms was preformed following the method described by Ferreira et al. (1991) as abovementioned procedures.

\subsection{Statistical Analysis}

All experiments were set up in a complete randomized design. One-way ANOVA was used to analyze differences between antagonistic inhibitor effect and linear growth of pathogenic fungi in vitro. A general linear model option of the analysis system SAS[11] was used to perform the ANOVA. Duncan's multiple range test at $\mathrm{P}<0.05$ level was used for means separation[12].

\section{Results and Discussion}

\subsection{Effect of Essential Oils on Antagonistic Ability}

Application of essential oil is a very attractive method for controlling plant diseases. Essential oils and their components are gaining increasing interest because of their relatively safe status, their wide acceptance by consumers, and their exploitation for potential multi-purpose functional uses[13]. Recently, interest has been shown in combining microbial biocontrol agents with other chemical components to increase their activity against plant pathogens. Essential oils have been used successfully in combination with a variety of treatments, such as antibacterial agents, mild heat and salt compounds[14]. Also among other chemical products, aromatic plants possess essential oils resulting from secondary metabolism. These substances have a great eco- nomic potential, especially in the food, pharmaceutical and perfumery sectors. Thus, the number of studies on the chemical composition and biological properties of these oils, as well as the taxonomic, environmental and cultivation factors that lead to variation in their quantity and quality, has been increasing[15].

In the present work, essential oils, i.e. Cinnamon, Clove and Thyme at different concentration were evaluated for their effect on the antagonistic ability of $T$. harzianum and $T$. viride against $S$. sclerotiorum and $S$. minor, in vitro conditions.

The obtained results in Table (1) and Fig (1) revealed in general that all tested essential oils enhanced the antagonistic ability of fungal bio-agents. In this regards, Cinnamon oil have superior enhancement for increasing the antagonistic efficacy of $T$. harzianum, and $T$. viride followed by Thyme and Clove oils at all used concentrations. Data also showed that the antagonistic efficacy was increased as the concentration increased of tested essential oils.

Similar trend was also observed for the antagonistic ability of bacteria bioagents, results presented in Table (2) and Fig (2) revealed that in general Cinnamon oil have more enhancing effect on the antagonistic ability than that of both Thyme and Clove oils at all tested concentrations. Moreover, it was observed that the pathogenic fungal growth fluctuated at the same used concentration depending on the antagonist. In this regard, it was observed that the pathogenic fungal growth reduced between $77.7-83.3 \%$ and $72.2-72.2 \%$ (Fig. 2) when grown in dual culture against $B$. subtilis and $P$. fluorescens, respectively in growth media supplemented with Cinnamon oil at concentration of $1 \%$ comparing with control treatment which ranged as $24.4-21.1 \%$ and $13.3-13.3 \%$, in respective order to the two bioagents. In this concern, essential oils are promising alternative compounds which have an inhibitory activity on the growth of pathogens. It is possible that essential oils could be used in plant disease control as the main or as adjuvant antimicrobial compounds. Recently, there has been considerable demand for the discovery of new natural antimicrobials[16]. Plant products with antimicrobial properties have notably obtained attention as possible applicants in order to prevent bacterial and fungal growth[17]. This means that essential oils could be used as alternative anti-bacterial and anti-fungal treatments[3]. It is evident from reviews $[18,19]$ that some plant extracts and essential oils exhibited antifungal properties. Essential oil of Juniperus communis may be applicable against a range of damping-off diseases[20]. Furthermore, studies on the effectiveness of nine essential oils to control the growth of mycotoxins producing moulds reveald that, clove, cinnamon and oregano were able to prevent the growth of Aspergillus parasiticus and Fusarium moniliforme[21].

\subsection{Effect of Plant Resistance Inducers on Antagonistic Ability}

Results in Table (3) and Fig (3) showed the efficacy of some plant inducers on the antagonistic ability of $T$. har- 
zianum and $T$. viride against $S$. sclerotiorum and $S$. minor.

Presented data showed that concentrations used of calcium chloride enhance significantly the antagonistic ability of $T$. harzianum and $T$. viride, respectively. Only, T. harzianum, exhibit complete reduction (100\%) for the two pathogenic fungal growth at concentration of 2 and $4 \%$ comparing with the range of $48.8-50 \%$ (Fig. 3) in medium free of calcium chloride. Similar observation was recorded with $T$. viride at concentration of $4 \%$ comparing with the range of $31.1-33.3 \%$ in medium free of calcium chloride.

Similar trend was also observed with the mixture of $\mathrm{Hu}$ - mic and Folic acids whereas presented data (Table, 3) revealed that concentrations of 0.4 and $0.6 \%$ increased the antagonistic ability of $T$. harzianum and $T$. viride causing complete reduction $(100 \%)$ of pathogenic fungal growth comparing to (48.8-50.0\%) and (31.1-33.3\%) respectively in medium free of Humic and Folic acids mixture.

Also, the obtained data revealed that Potassium bicarbonate have significant enhancement effect on the antagonistic ability of tested fungi followed by Sodium bicarbonate and Potassium mono-hydrogen phosphate, respectively.

Table 1. Effect of some essential oils on the antagonistic ability of Trichoderma spp. against Sclerotinia spp. in vitro

\begin{tabular}{|c|c|c|c|c|c|}
\hline \multirow{4}{*}{ Essential oils } & \multirow{4}{*}{ Concentration (\%) } & \multicolumn{4}{|c|}{ Antagonistic fungi } \\
\hline & & \multicolumn{2}{|c|}{ T. harzianum } & \multicolumn{2}{|c|}{ T. viride } \\
\hline & & \multicolumn{4}{|c|}{ Sclerotinia spp. } \\
\hline & & S. sclerotiorum & S. minor & S. sclerotiorum & S. minor \\
\hline control & 0 & $46^{*} \mathrm{f}$ & $45 \mathrm{f}$ & $62 \mathrm{~h}$ & $60 \mathrm{~h}$ \\
\hline \multirow{3}{*}{ Cinnamon } & 0.25 & $24 \mathrm{~d}$ & $25 \mathrm{~d}$ & $34 \mathrm{e}$ & $30 \mathrm{e}$ \\
\hline & 0.5 & $17 \mathrm{bc}$ & $20 \mathrm{c}$ & $25 \mathrm{~d}$ & $24 \mathrm{~d}$ \\
\hline & 1.0 & $15 \mathrm{~b}$ & $10 \mathrm{a}$ & $16 \mathrm{~b}$ & $10 \mathrm{a}$ \\
\hline \multirow{3}{*}{ Clove } & 0.25 & $43 \mathrm{f}$ & $37 \mathrm{e}$ & $60 \mathrm{~h}$ & $43 \mathrm{f}$ \\
\hline & 0.5 & $38 \mathrm{f}$ & $27 \mathrm{~cd}$ & $52 \mathrm{~g}$ & $28 \mathrm{~d}$ \\
\hline & 1.0 & $30 \mathrm{e}$ & $19 \mathrm{bc}$ & $40 \mathrm{fg}$ & $16 \mathrm{bc}$ \\
\hline \multirow{3}{*}{ Thyme } & 0.25 & $36 \mathrm{e}$ & $35 \mathrm{e}$ & $25 \mathrm{c}$ & $41 \mathrm{f}$ \\
\hline & 0.5 & $30 \mathrm{e}$ & $26 \mathrm{c}$ & $19 \mathrm{bc}$ & $32 \mathrm{e}$ \\
\hline & 1.0 & $20 \mathrm{c}$ & $10 \mathrm{a}$ & $11 \mathrm{ab}$ & $16 \mathrm{~b}$ \\
\hline
\end{tabular}

${ }^{*}$ Linear fungal growth $(\mathrm{mm})$

Mean values within columns followed by the same letter are not significantly different $(\mathrm{P} \leq 0.05)$.
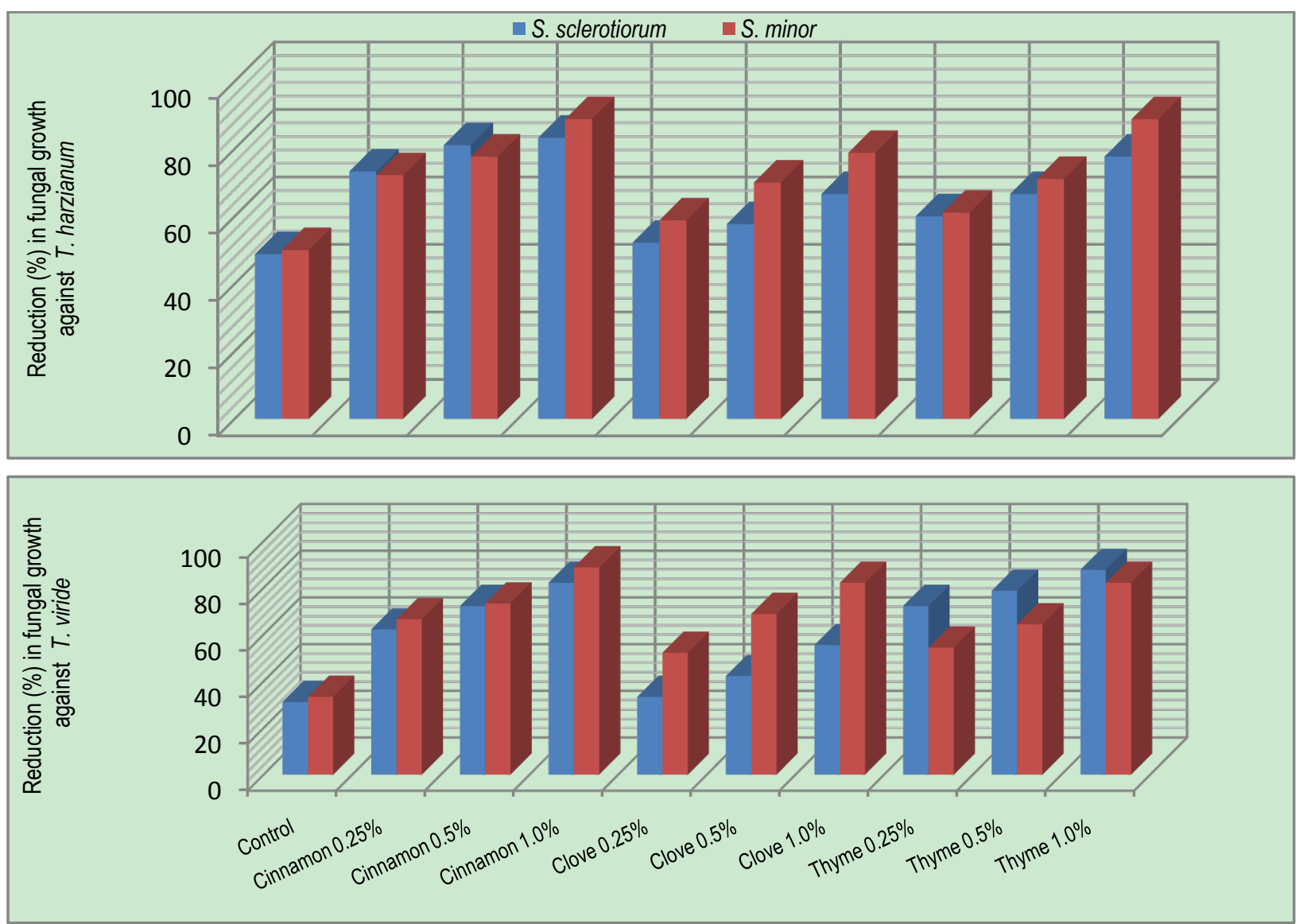

Figure 1. Increase in antagonistic ability of Trichoderma spp. against Sclerotinia spp. in response to different concentrations of essential oils in vitro 
Table 2. Effect of some essential oils on the antagonistic ability of antagonistic bacteria against Sclerotinia spp. in vitro

\begin{tabular}{|c|c|c|c|c|c|}
\hline \multirow{4}{*}{ Essential oils } & \multirow{4}{*}{ Concentration $(\%)$} & \multicolumn{4}{|c|}{ Antagonistic bacteria } \\
\hline & & \multicolumn{2}{|c|}{ Bacillus subtilis } & \multicolumn{2}{|c|}{ Pseudomonas fluorescens } \\
\hline & & \multicolumn{4}{|c|}{ Sclerotinia spp. } \\
\hline & & S. sclerotiorum & S. minor & S. sclerotiorum & S. minor \\
\hline control & 0 & $68 * \mathrm{~b}$ & $71 \mathrm{ab}$ & $78 \mathrm{a}$ & $78 \mathrm{a}$ \\
\hline \multirow{3}{*}{ Cinnamon } & 0.25 & $40 \mathrm{ef}$ & $65 \mathrm{~b}$ & $60 \mathrm{bc}$ & $60 \mathrm{bc}$ \\
\hline & 0.5 & $25 \mathrm{~h}$ & $50 \mathrm{~d}$ & $45 \mathrm{e}$ & $45 \mathrm{e}$ \\
\hline & 1.0 & $15 \mathrm{i}$ & $20 \mathrm{~h}$ & $25 \mathrm{~h}$ & $25 \mathrm{~h}$ \\
\hline \multirow{3}{*}{ Clove } & 0.25 & $65 \mathrm{~b}$ & $66 \mathrm{~b}$ & $75 \mathrm{c}$ & $75 \mathrm{c}$ \\
\hline & 0.5 & $60 \mathrm{bc}$ & $55 \mathrm{c}$ & $55 \mathrm{c}$ & $55 \mathrm{c}$ \\
\hline & 1.0 & $50 \mathrm{~d}$ & $45 \mathrm{e}$ & $35 \mathrm{~g}$ & $35 \mathrm{~g}$ \\
\hline \multirow{3}{*}{ Thyme } & 0.25 & $65 \mathrm{~b}$ & $60 \mathrm{bc}$ & $67 \mathrm{~b}$ & $67 \mathrm{~b}$ \\
\hline & 0.5 & $50 \mathrm{~d}$ & $50 \mathrm{~d}$ & $42 \mathrm{ef}$ & $42 \mathrm{ef}$ \\
\hline & 1.0 & $25 \mathrm{~h}$ & $30 \mathrm{~g}$ & $31 \mathrm{~g}$ & $31 \mathrm{~g}$ \\
\hline
\end{tabular}

${ }^{*}$ Linear fungal growth $(\mathrm{mm})$

Mean values within columns followed by the same letter are not significantly different $(\mathrm{P} \leq 0.05)$.
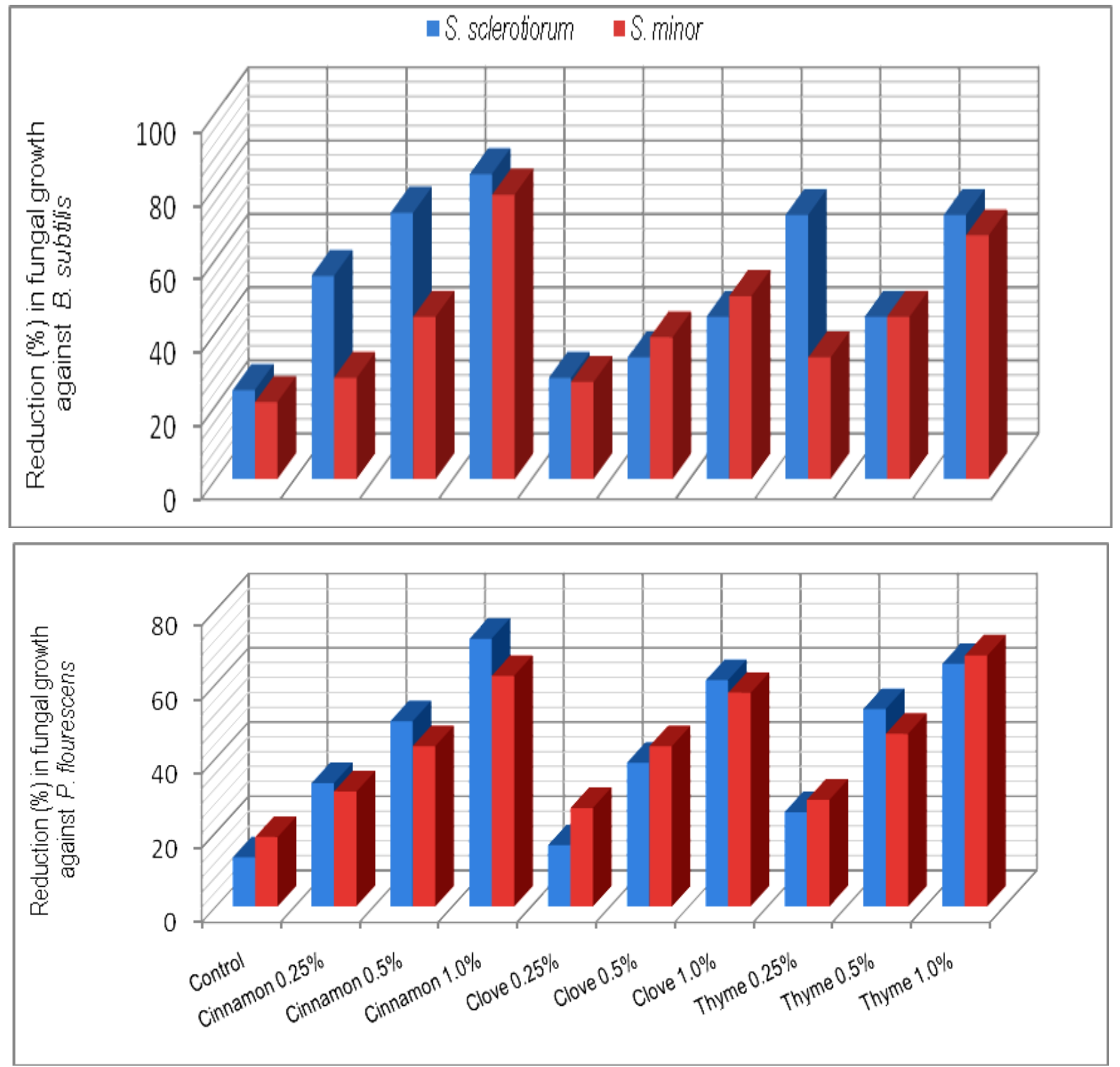

Figure 2. Increase in antagonistic ability of bacterial bio-agents against Sclerotinia spp. in response to different concentrations of essential oils in vitro 
M. M. Abdel-Kader et al.: Occurrence of Sclerotinia Foliage Blight Disease of Cucumber and Pepper Plants under Protected Cultivation System in Egypt II. Bio-Control Measures against Sclerotinia Spp. in Vitro

Table 3. Effect of some chemical inducers on the antagonistic ability of Trichoderma spp. against Sclerotinia spp. in vitro

\begin{tabular}{|c|c|c|c|c|c|}
\hline \multirow{4}{*}{ Chemical inducers } & \multirow{4}{*}{$\begin{array}{c}\text { Concentra- } \\
\text { tion } \\
(\%)\end{array}$} & \multicolumn{4}{|c|}{ Antagonistic fungi } \\
\hline & & \multicolumn{2}{|c|}{ T. harzianum } & \multicolumn{2}{|c|}{ T. viride } \\
\hline & & \multicolumn{4}{|c|}{ Sclerotinia spp. } \\
\hline & & S. sclerotiorum & S. minor & S. sclerotiorum & S. minor \\
\hline Control & 0 & $46^{*} \mathrm{f}$ & $45 \mathrm{f}$ & $62 \mathrm{~h}$ & $60 \mathrm{~h}$ \\
\hline \multirow{3}{*}{ Calcium chloride } & 1.0 & $31 \mathrm{~d}$ & $37 \mathrm{de}$ & $59 \mathrm{~g}$ & $52 \mathrm{~g}$ \\
\hline & 2.0 & $0 \mathrm{a}$ & $31 \mathrm{~d}$ & $57 \mathrm{~g}$ & $38 \mathrm{de}$ \\
\hline & 4.0 & $0 \mathrm{a}$ & $0 \mathrm{a}$ & $0 \mathrm{a}$ & $0 \mathrm{a}$ \\
\hline \multirow{3}{*}{ Sodium bicarbonate } & 1.0 & $38 \mathrm{de}$ & $43 \mathrm{f}$ & $45 \mathrm{e}$ & $52 \mathrm{~g}$ \\
\hline & 2.0 & $29 \mathrm{~cd}$ & $35 \mathrm{~d}$ & $38 \mathrm{de}$ & $40 \mathrm{ef}$ \\
\hline & 4.0 & $20 \mathrm{~b}$ & $28 \mathrm{~cd}$ & $20 \mathrm{~b}$ & $34 \mathrm{~d}$ \\
\hline \multirow{3}{*}{ Potassium bicarbonate } & 1.0 & $31 \mathrm{~d}$ & $33 \mathrm{~d}$ & $27 \mathrm{c}$ & $38 \mathrm{de}$ \\
\hline & 2.0 & $18 \mathrm{~b}$ & $28 \mathrm{c}$ & $15 \mathrm{~b}$ & $31 \mathrm{~d}$ \\
\hline & 4.0 & $0 \mathrm{a}$ & $0 \mathrm{a}$ & $0 \mathrm{a}$ & $0 \mathrm{a}$ \\
\hline \multirow{3}{*}{$\begin{array}{l}\text { Potassium phosphate } \\
\qquad\left(\mathrm{K}_{2} \mathrm{HPO}_{4}\right)\end{array}$} & 1.0 & $42 \mathrm{f}$ & $43 \mathrm{f}$ & $58 \mathrm{gh}$ & $53 \mathrm{~g}$ \\
\hline & 2.0 & $39 \mathrm{de}$ & $36 \mathrm{~d}$ & $52 \mathrm{~g}$ & $48 \mathrm{fg}$ \\
\hline & 4.0 & $0 \mathrm{a}$ & 0 & $0 \mathrm{a}$ & $0 \mathrm{a}$ \\
\hline \multirow{3}{*}{$\begin{array}{c}\text { Humic }+ \text { Folic acids } \\
(1: 1)\end{array}$} & 0.2 & $38 \mathrm{de}$ & $34 \mathrm{~d}$ & $53 \mathrm{f}$ & $48 \mathrm{fg}$ \\
\hline & 0.4 & $0 \mathrm{a}$ & $0 \mathrm{a}$ & $0 \mathrm{a}$ & $0 \mathrm{a}$ \\
\hline & 0.6 & $0 \mathrm{a}$ & $0 \mathrm{a}$ & $0 \mathrm{a}$ & $0 \mathrm{a}$ \\
\hline
\end{tabular}

${ }^{*}$ Linear fungal growth $(\mathrm{mm})$

Mean values within columns followed by the same letter are not significantly different $(\mathrm{P} \leq 0.05)$.

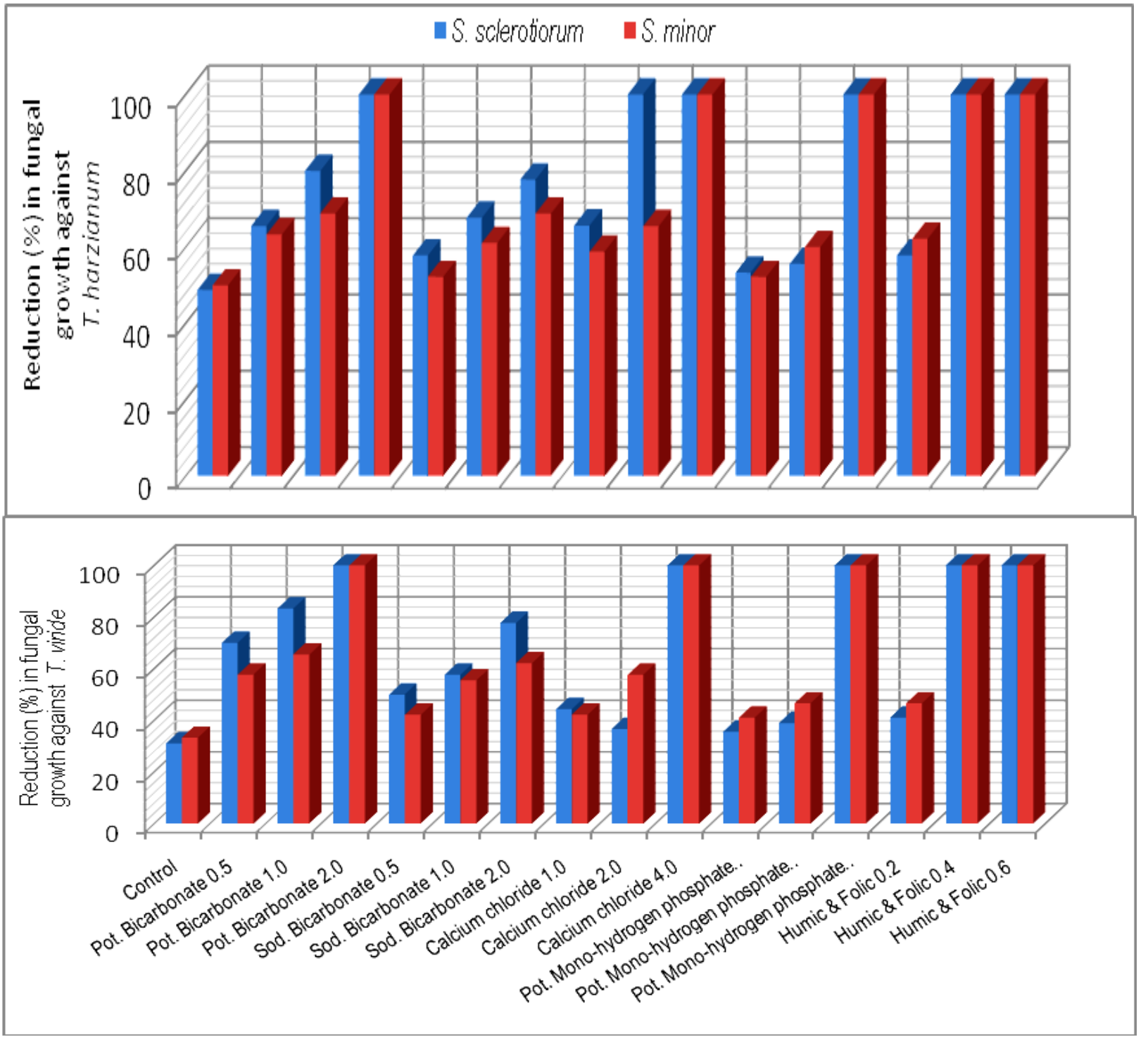

Figure 3. Increase in antagonistic ability of Trichoderma spp. against Sclerotinia spp. in response to different concentrations of some chemical inducers in vitro 
Data also revealed that Potassium bicarbonate concentrations showed lesser effect on the antagonistic ability of tested fungal bio-agents. In this concern it was observed that the reduction in linear growth of pathogenic fungi against antagonists fluctuated referring to concentration used for each pathogenic fungus. Enhancement of antagonistic ability of tested fungal bio-agents could be arranged in descending order as T. harzianum and T. viride.

The effect of Calcium chloride on the antagonistic ability of bacteria $B$. subtilis and $P$. fluorescens against $\mathrm{S}$. sclerotiorum and S. minor was evaluated in vitro. Data in Table (4) and Fig (4) showed that the antagonistic efficacy of antagonistic bacteria against pathogenic fungal growth increased as the concentration of calcium chloride increased in growth media. In this regard, all tested pathogenic fungi showed high sensitivity against the antagonist B. subtilis where their growth reduced by $81.1,83.3 \%$ (Fig. 4 ) in the presence of calcium chloride at $4 \%$ in growth media. Another feature at a lesser extent was observed with $P$. fluorescencs that they could reduced the fungal growth of $S$. sclerotiorum and S. minor to $75.5,72.2 \%$, respectively at the same concentration of $4 \%$. Concerning Humic and folic acids mixture the obtained results (Table 4 \& Fig.4) showed that the efficacy of the antagonistic ability of tested bio-agents increased in parallel with increasing the concentrations of Humic and folic acids mixture reaching its maximum at the highest concentration. In this regards, highest inhibition in pathogenic fungal growth of S. sclerotiorum and $S$. minor, was observed when they grown against the antagonistic bacteria $B$. subtilis and $P$. fluorescens in the presence of $0.6 \%$ of Humic and folic acids mixture in the growth media.

Table 4. Effect of some chemical inducers on the antagonistic ability of antagonistic bacteria against Sclerotinia spp. in vitro

\begin{tabular}{|c|c|c|c|c|c|}
\hline \multirow{4}{*}{ Chemical inducers } & \multirow{4}{*}{$\begin{array}{l}\text { Concentra- } \\
\text { tion }(\%)\end{array}$} & \multicolumn{4}{|c|}{ Antagonistic bacteria } \\
\hline & & \multicolumn{2}{|c|}{ Bacillus subtilis } & \multicolumn{2}{|c|}{ Pseudomonas fluorescens } \\
\hline & & \multicolumn{4}{|c|}{ Sclerotinia spp. } \\
\hline & & S. sclerotiorum & S. minor & S. sclerotiorum & S. minor \\
\hline Control & 0 & $58^{*} \mathrm{c}$ & $66 \mathrm{~b}$ & $78 \mathrm{a}$ & $72 \mathrm{a}$ \\
\hline \multirow{3}{*}{ Potassium bicarbonate } & 1.0 & $50 \mathrm{~cd}$ & $58 \mathrm{c}$ & $71 \mathrm{a}$ & $56 \mathrm{c}$ \\
\hline & 2.0 & $45 \mathrm{de}$ & $52 \mathrm{c}$ & $69 \mathrm{ab}$ & $52 \mathrm{c}$ \\
\hline & 4.0 & $41 \mathrm{e}$ & $47 \mathrm{de}$ & $64 \mathrm{~b}$ & $48 \mathrm{~d}$ \\
\hline \multirow{3}{*}{ Sodium bicarbonate } & 1.0 & $55 \mathrm{c}$ & $61 \mathrm{bc}$ & $72 \mathrm{a}$ & $68 \mathrm{~b}$ \\
\hline & 2.0 & $51 \mathrm{~cd}$ & $57 \mathrm{c}$ & $67 \mathrm{~b}$ & $62 \mathrm{~b}$ \\
\hline & 4.0 & $43 \mathrm{e}$ & $52 \mathrm{c}$ & $60 \mathrm{bc}$ & $56 \mathrm{c}$ \\
\hline \multirow{3}{*}{ Calcium chloride } & 1.0 & $30 \mathrm{f}$ & $35 \mathrm{ef}$ & $44 \mathrm{de}$ & $46 \mathrm{de}$ \\
\hline & 2.0 & $25 \mathrm{~g}$ & $26 \mathrm{~g}$ & $35 \mathrm{f}$ & $40 \mathrm{e}$ \\
\hline & 4.0 & $15 \mathrm{~h}$ & $17 \mathrm{~h}$ & $22 \mathrm{~g}$ & $25 \mathrm{~g}$ \\
\hline \multirow{3}{*}{$\begin{array}{l}\text { Potassium phosphate } \\
\qquad\left(\mathrm{K}_{2} \mathrm{PO}_{4}\right)\end{array}$} & 1.0 & $50 \mathrm{~cd}$ & $59 \mathrm{c}$ & $68 \mathrm{~b}$ & $62 \mathrm{~b}$ \\
\hline & 2.0 & $41 \mathrm{e}$ & $48 \mathrm{~d}$ & $50 \mathrm{~cd}$ & $46 \mathrm{de}$ \\
\hline & 4.0 & 36 ef & 39 ef & $40 \mathrm{e}$ & $38 \mathrm{ef}$ \\
\hline \multirow{3}{*}{ humic + Folic acids } & 0.2 & $43 \mathrm{e}$ & $46 \mathrm{de}$ & $46 \mathrm{de}$ & $47 \mathrm{~d}$ \\
\hline & 0.4 & $30 \mathrm{f}$ & $37 \mathrm{ef}$ & $34 \mathrm{f}$ & $41 \mathrm{e}$ \\
\hline & 0.6 & $15 \mathrm{~h}$ & $18 \mathrm{~h}$ & $29 \mathrm{fg}$ & $30 \mathrm{f}$ \\
\hline
\end{tabular}

${ }^{*}$ Linear fungal growth $(\mathrm{mm})$

Mean values within columns followed by the same letter are not significantly different $(\mathrm{P} \leq 0.05)$.

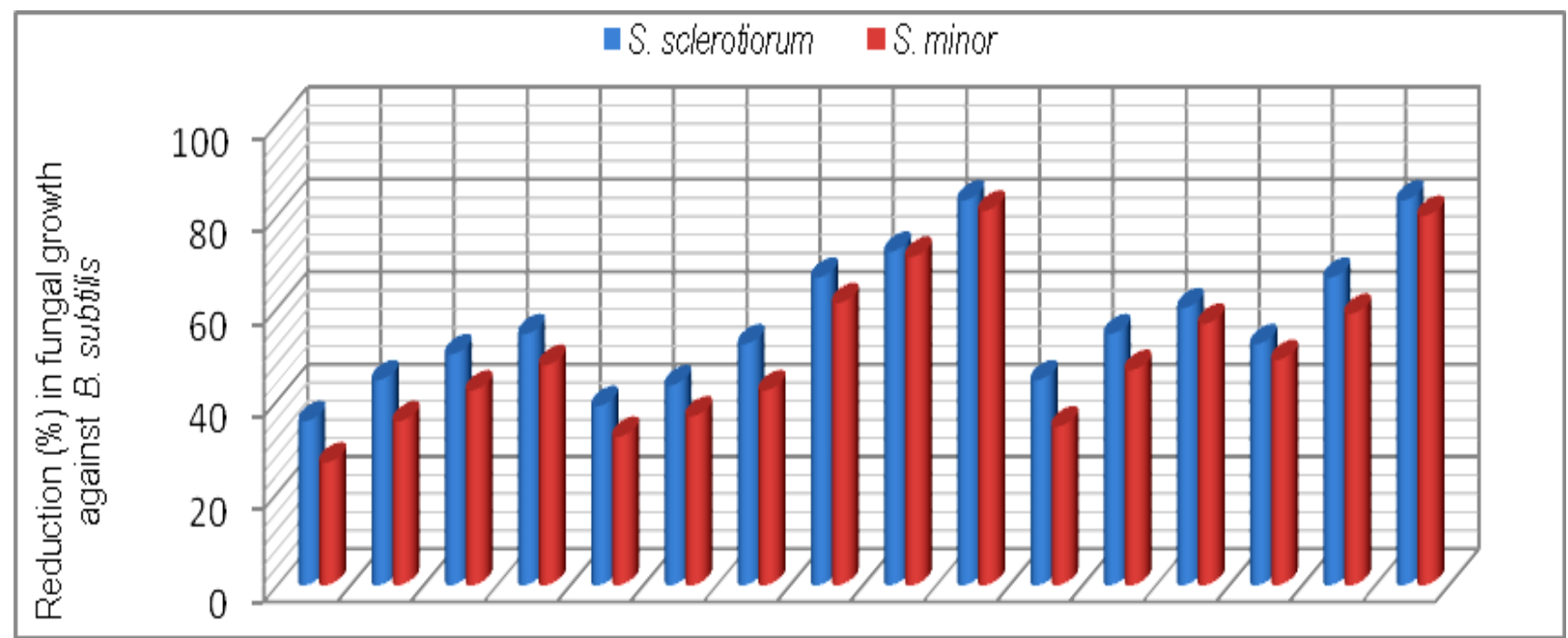




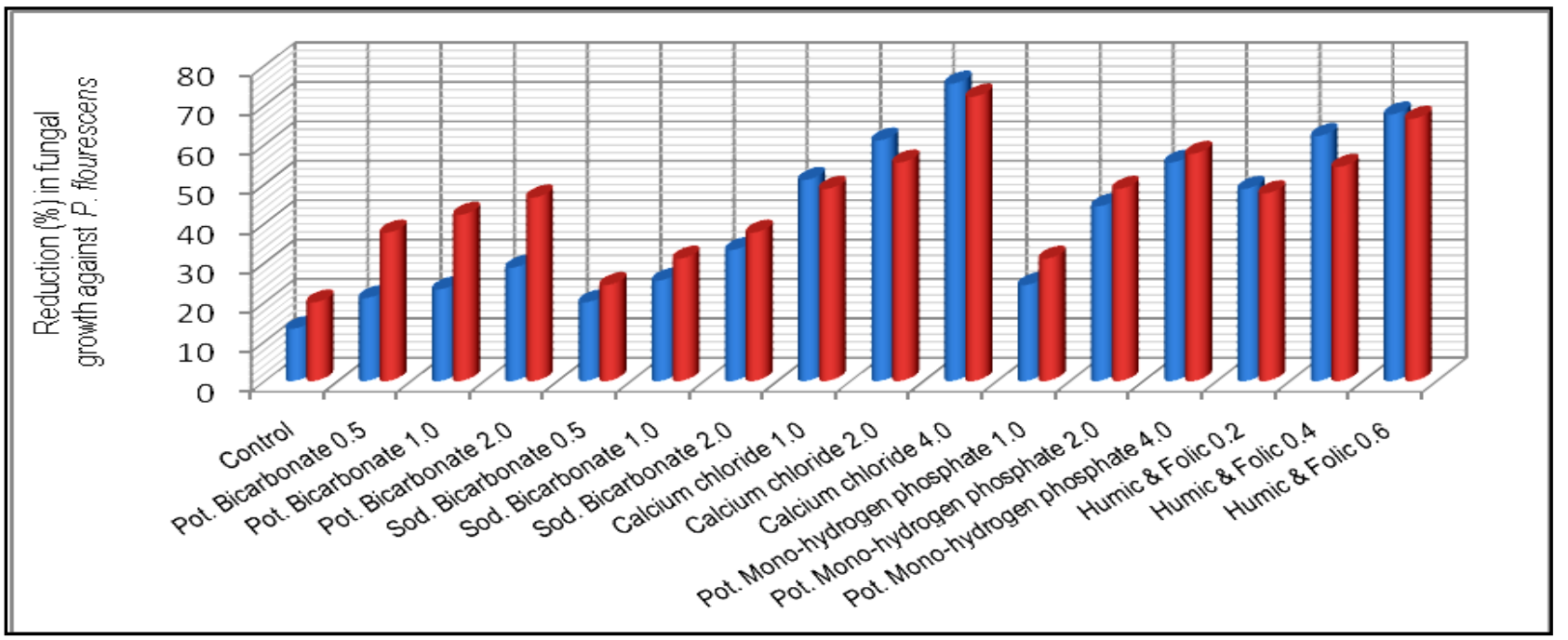

Figure 4. Increase in antagonistic ability of bacterial bio-agents against Sclerotinia spp in response to different concentrations of chemical inducers in vitro

Regarding the effect of different concentrations of Potassium, Sodium bicarbonates and Potassium mono-hydrogen phosphate on the antagonistic ability of bacteria against pathogenic fungi the obtained results presented in Table (4) and Fig (4). Tabulated data revealed that different concentrations of chemicals used have positive effect for enhancing the efficacy of antagonistic ability of tested bio-agents. Potassium mono-hydrogen phosphate showed superior effect in this regard followed by Potassium bicarbonates and Sodium bicarbonate, respectively. Data also showed that the minimum growth records for $S$. sclerotiorum and $S$. minor was $36 \mathrm{~mm}(60.0 \%)$ and $39 \mathrm{~mm}(56.6 \%)$ against B. subtilis on medium supplemented with $4 \%$ of Potassium mono -hydrogen phosphate comparing, in respective order, with $58 \mathrm{~mm}(35.5 \%)$ and $66 \mathrm{~mm}(26.6 \%)$ in medium free of chemical tested.

Similar records confirm the obtained results in the present study. Many investigations concerning the use of abiotic factors for induction of plant resistance against several diseases have been accumulated. Potassium salts $\left(\mathrm{K}_{2} \mathrm{HPO}_{4}\right.$ or $\mathrm{KNO}_{3}$ ) as a chemical agent for induction of plant resistance had great attention in many of these reports [4, 5]. In this concern, spraying cucumber plants with $\mathrm{K}_{2} \mathrm{HPO}_{4}$ induced resistance against downy and powdery mildews and increased fruit yield per plant under commercial greenhouse conditions[22, 23, 24, 25, 26]. Furthermore, there has been considerable interest in the use of sodium bicarbonate, potassium bicarbonate and potassium phosphate for controlling various fungal diseases in plants[22, 23, 27, 28, 29]. Spraying plants with either sodium bicarbonate or potassium bicarbonate solution provided good control of several plant diseases[26, 29, 30]. Also, calcium chloride had been recorded to have antifungal effect and provided broad -spectrum protection against the postharvest pathogens of $P$. expansum and B. cinerea in apple[31]. Moreover, under in vitro and in vivo conditions, all tested concentrations of hydrogen peroxide, calcium chloride and chitosan were able to reduce the linear growth and spore germination of $B$. cinerea; R. stolonifer; $P$. digitatum and $P$. italicum and complete inhibition of linear growth and spore germination was obtained with concentrations of 1.5 and $2.0 \%$ of all treatments[32]. Humic acid (HA) is a heterogeneous mixture of many compounds with generally similar chemical properties it performs various functions in the soil and on plant growth. Humic substances have been early recorded to have appositive effect against plant pathogens[8, 9]. Also, many studies[6, 7] showed that Fulvic acid (FA) have a greater effect on cells biological activities than humic acids (HA) compounds. The addition of $500 \mathrm{mgl}^{-1}$ of humic acids on the growth medium completely eliminated the inhibition of $P$. ultimum by $R$. radiobacter [33]. Furthermore, in vitro, humic acid at $15.0 \%(\mathrm{v} / \mathrm{v})$ reduced significantly the radical growth and spore germination of Fusarium solani the causal agent of dry root rot[34].

\subsection{Effect of Plant Extracts on Antagonistic Ability}

The effect of some plant extracts, i.e. Halfa Bar, Ginger and Bay laurel on the antagonistic ability of Trichoderma spp. against pathogenic fungi Sclerotinia spp. was estimated in vitro. Data in Table (5) and Fig (5) revealed that all plant extract at different concentrates could enhance the antagonistic ability of tested fugal bio-agents. In this concern, the antagonistic efficacy of $T$. harzianum against pathogenic fungi increased in respective order from the range of $(50.0-53.3 \%)$ in media free of plant extracts up to $(57.7-62.2 \%),(60.0-60.0 \%)$ and $(60.0-58.8 \%)$ at the highest concentration (4\%) of Halfa Bar, Ginger and Bay laurel, respectively. Meanwhile, the antagonistic efficacy of $T$. viride against pathogenic fungi also increased from the range of $(50.0-57.7 \%)$, in media free of plant extracts up to $(61.1-58.8 \%),(60.0-70.0 \%)$ and $(60.0-66.6 \%)$ at the highest concentration of tested extracts. Furthermore, the effect of some plant extracts on the antagonistic ability of bacteria and yeast against pathogenic fungi was also evaluated in vitro. Data in Table (6) and Fig (6) revealed that all tested concentrations of plant extracts could enhance the efficacy of 
antagonistic ability of bacterial bio-agents. Data also, showed that no announced increase in the antagonistic ability was observed. Significant increase in antagonistic ability was observed only with the highest concentration of tested plant extracts. Moreover, no significant differences were observed between the tested Halfa Bar, Ginger and Bay laurel plant extracts at all used concentrations. The use of plants or plant materials as fungicides is of a great importance and needs more attention[35] and various plant products like gum, oil, resins etc. are used as fungicidal compounds[36, 37]. In this regards, several workers studied the effect of various plants extracts against pathogenic microorganisms. Also, extracts of Eupartrium cannabinum completely inhibited the mycelia growth of Pythium debaryanum, $R$. solani and S. rolfsii[38]. Some plant extracts and essential oils exhibited antifungal properties[19]. Several reports indicated that plant spices containing carvacrol, eugenol and thymol (phenolic compounds) had the highest antibacterial performances[39]. Alkaloids, flavonoids, isoflavonoids, tanins, cumarins, glycosides, terpens and phenolic compounds were synthesized by plants as secondary metabolites[15]. In agricultural studies, these compounds have broad-spectrum activities against fungi, nematodes, and insects[40, 41, 42]. Plant spices offer a promising alternative for food safety and plant protection. Inhibitory activity of spices and their derivatives on the growth of bacteria, yeasts, fungi and microbial toxin synthesis was reported[16, 43]. Moreover, antifungal activity of spices and their derivatives were studied by viable cells count, mycelial growth and mycotoxin synthesis. However, there is little information on spices and their derivative's action on/in a fungal cell. In general, inhibitory action of natural products on moulds involves cytoplasm granulation, cytoplasmic membrane rupture and inactivation and/or inhibition of intercellular and extracellular enzymes. These biological events could take place separately or concomitantly culminating with mycelial growth inhibition (Cowan 1999).

Table 5. Effect of some plant extracts on the antagonistic ability of Trichoderma spp. against Sclerotinia spp. in vitro

\begin{tabular}{|c|c|c|c|c|c|}
\hline \multirow{4}{*}{ Plant extract } & \multirow{4}{*}{$\begin{array}{c}\text { Concentration } \\
(\%)\end{array}$} & \multicolumn{4}{|c|}{ Antagonistic fungi } \\
\hline & & \multicolumn{2}{|c|}{ T. harzianum } & \multicolumn{2}{|c|}{ T. viride } \\
\hline & & \multicolumn{4}{|c|}{ Sclerotinia spp. } \\
\hline & & S. sclerotiorum & S. minor & S. sclerotiorum & $S . \quad$ minor \\
\hline Control & 0 & $45^{*} \mathrm{a}$ & $42 \mathrm{a}$ & $45 \mathrm{a}$ & $38 \mathrm{~b}$ \\
\hline \multirow{3}{*}{ Halfa Bar } & 1.0 & $42 \mathrm{a}$ & $40 \mathrm{ab}$ & $41 \mathrm{a}$ & $33 \mathrm{~cd}$ \\
\hline & 2.0 & $40 \mathrm{ab}$ & $37 \mathrm{bc}$ & $37 \mathrm{bc}$ & $30 \mathrm{~d}$ \\
\hline & 4.0 & $38 \mathrm{~b}$ & $34 \mathrm{~cd}$ & $35 \mathrm{c}$ & $37 \mathrm{bc}$ \\
\hline \multirow{3}{*}{ Ginger } & 1.0 & $41 \mathrm{a}$ & $39 \mathrm{~b}$ & $40 \mathrm{ab}$ & $35 \mathrm{c}$ \\
\hline & 2.0 & $38 \mathrm{~b}$ & $37 \mathrm{bc}$ & $37 \mathrm{bc}$ & $31 \mathrm{~d}$ \\
\hline & 4.0 & $36 \mathrm{c}$ & $36 \mathrm{c}$ & $36 \mathrm{c}$ & $27 \mathrm{e}$ \\
\hline \multirow{3}{*}{ Bay laurel } & 1.0 & $40 \mathrm{ab}$ & $41 \mathrm{a}$ & $42 \mathrm{a}$ & $36 \mathrm{c}$ \\
\hline & 2.0 & $38 \mathrm{~b}$ & $38 \mathrm{~b}$ & $39 \mathrm{~b}$ & $32 \mathrm{~d}$ \\
\hline & 4.0 & $36 \mathrm{c}$ & $37 \mathrm{bc}$ & $36 \mathrm{c}$ & $30 \mathrm{~d}$ \\
\hline
\end{tabular}

${ }^{*}$ Linear fungal growth $(\mathrm{mm})$

Mean values within columns followed by the same letter are not significantly different $(\mathrm{P} \leq 0.05)$.
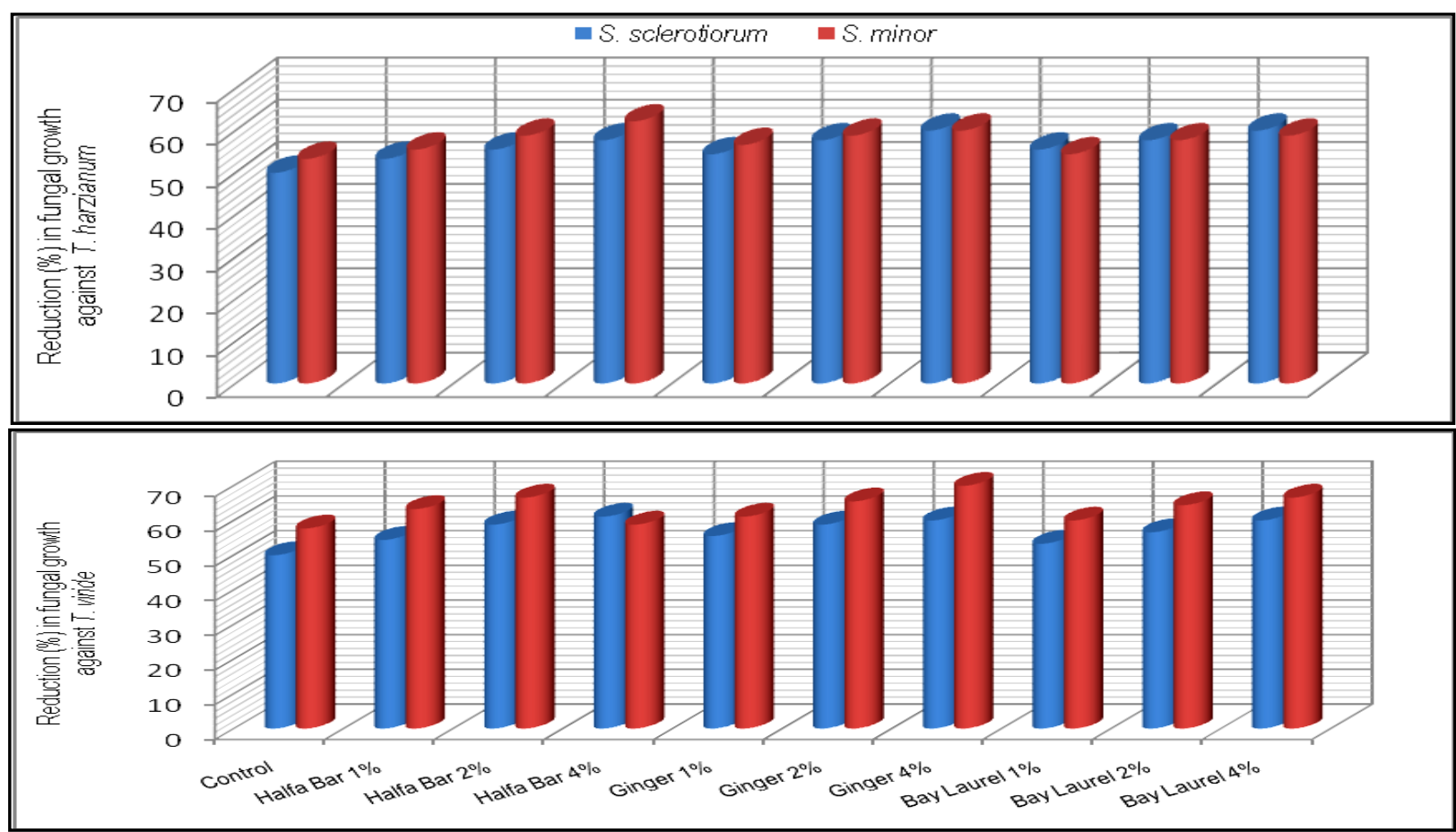

Figure 5. Increase in antagonistic ability of Trichoderma spp. in response to different concentrations of some plant extracts in vitro 

under Protected Cultivation System in Egypt II. Bio-Control Measures against Sclerotinia Spp. in Vitro

Table 6. Effect of some plant extracts on the antagonistic ability of antagonistic bacteria against Sclerotinia spp. in vitro

\begin{tabular}{|c|c|c|c|c|c|}
\hline \multirow{4}{*}{ Plant extract } & \multirow{4}{*}{$\begin{array}{c}\text { Concentration } \\
(\%)\end{array}$} & \multicolumn{4}{|c|}{ Antagonistic bacteria } \\
\hline & & \multicolumn{2}{|c|}{ B. subtilis } & \multicolumn{2}{|c|}{ P. fluorescens } \\
\hline & & \multicolumn{4}{|c|}{ Sclerotinia spp. } \\
\hline & & S. sclerotiorum & S. minor & S. sclerotiorum & S. minor \\
\hline Control & 0 & $45^{*} \mathrm{a}$ & $42 \mathrm{a}$ & $45 \mathrm{a}$ & $38 \mathrm{~b}$ \\
\hline \multirow{3}{*}{ Halfa Bar } & 1.0 & $43 \mathrm{a}$ & $40 \mathrm{a}$ & $41 \mathrm{a}$ & $35 \mathrm{~b}$ \\
\hline & 2.0 & $42 \mathrm{a}$ & $39 \mathrm{~b}$ & $38 \mathrm{~b}$ & $32 \mathrm{bc}$ \\
\hline & 4.0 & $39 \mathrm{~b}$ & $36 \mathrm{bc}$ & $36 \mathrm{bc}$ & $30 \mathrm{bc}$ \\
\hline \multirow{3}{*}{ Ginger } & 1.0 & $41 \mathrm{a}$ & $39 \mathrm{~b}$ & $40 \mathrm{a}$ & $35 \mathrm{~b}$ \\
\hline & 2.0 & $39 \mathrm{~b}$ & $37 \mathrm{~b}$ & $37 \mathrm{~b}$ & $32 \mathrm{bc}$ \\
\hline & 4.0 & $37 \mathrm{~b}$ & $36 \mathrm{bc}$ & $36 \mathrm{bc}$ & $30 \mathrm{bc}$ \\
\hline \multirow{3}{*}{ Bay laurel } & 1.0 & $42 \mathrm{a}$ & $41 \mathrm{a}$ & $42 \mathrm{a}$ & $36 \mathrm{~b}$ \\
\hline & 2.0 & $38 \mathrm{~b}$ & $38 \mathrm{~b}$ & $39 \mathrm{~b}$ & $32 \mathrm{bc}$ \\
\hline & 4.0 & $36 \mathrm{~b}$ & $37 \mathrm{~b}$ & $35 \mathrm{bc}$ & $30 \mathrm{bc}$ \\
\hline
\end{tabular}

${ }^{*}$ Linear fungal growth $(\mathrm{mm})$

Mean values within columns followed by the same letter are not significantly different $(\mathrm{P} \leq 0.05)$.

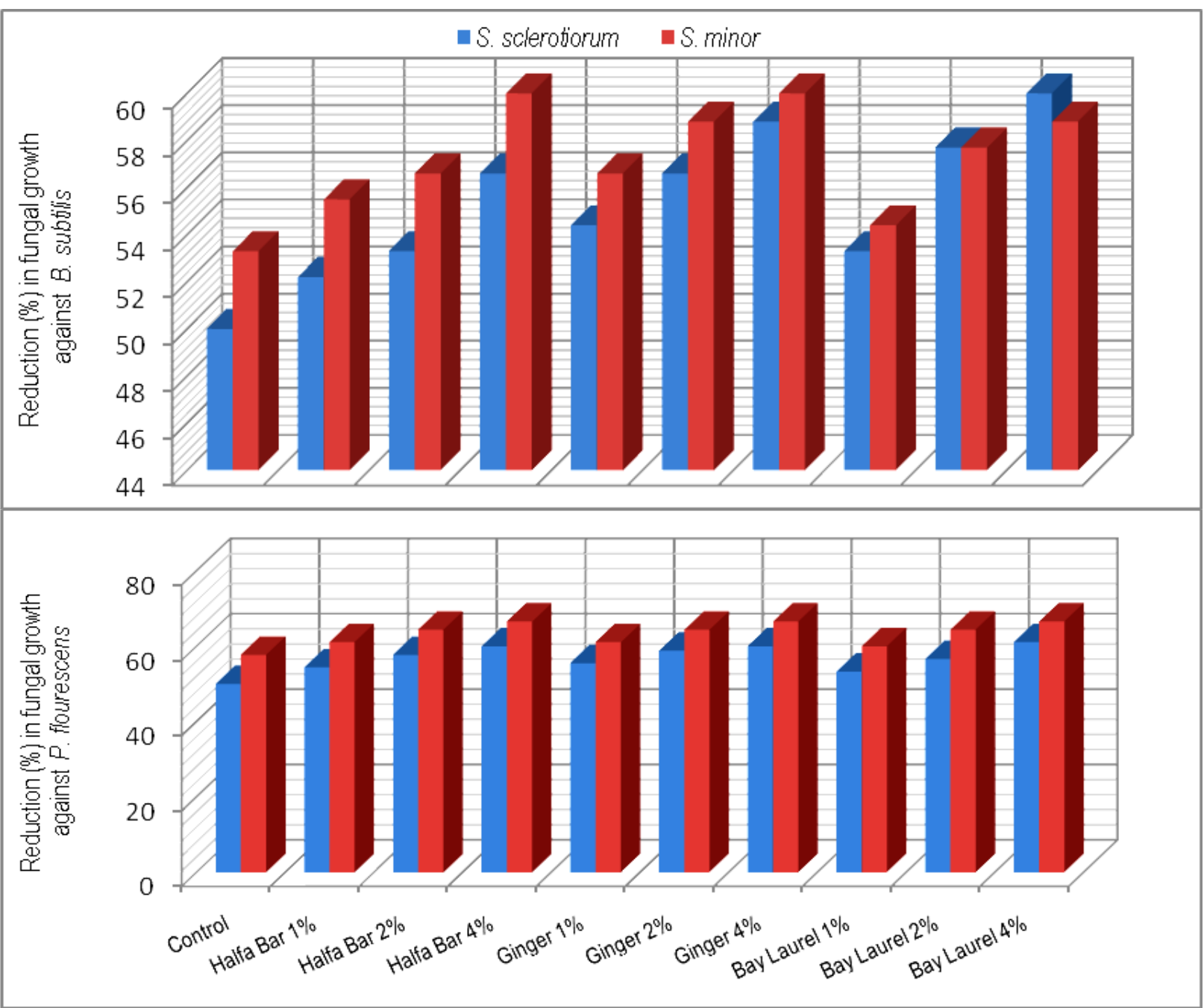

Figure 6. Increase in antagonistic ability of bacterial bio-agents in response to different concentrations of some plant extracts in vitro

\section{Conclusions}

The wide and indiscriminate use of chemical fungicides has been the cause of the appearance of resistant plant pathogens, leading to the occurrence of serious diseases. Due to this, there is an increasing interest to obtain alterna- tive antimicrobial agents for using in plant disease control systems. One of the main procedures used in the research of biologically active substances is a systematic screening for the interaction between microorganisms and plant products. The influence of some plant products and chemical inducers on the efficacy of the antagonistic ability of the biocontrol 
agents received attention in the present study. For this reason, laboratory tests for the biological antagonistic ability of the bioagents, i.e. Trichoderma harzianum, T. viride, Bacillus subtilis and Pseudomonas fluorescens against the soil-borne plant pathogens Sclerotinia sclerotiorum and S. minor are considered a simple approach for understanding as s small sector of biological systems in disease control under stress of different combined antifungal factors. Hence, the objective of this study was to determine if essential oils, plant resistance inducers and plant extracts could provide enhancing effect to the antagonistic ability of fungal and bacterial against pathogenic fungi $S$. sclerotiorum and $S$. minor. The obtained results in the present study has shown the potential of tested materials as effective inhibitors when combined factors with antagonistic bioagents. Considering their attribute and broad-spectrum activities, successful development of such compounds in combination with bioagents as antifungal could promise success in multipurpose biorational alternatives to conventional fungicides for the management of plant diseases.

\section{ACKNOLEDGEMENTS}

This work was supported financially by the Science and Technology Development Fund (STDF), Egypt, Grant No. 1059.

\section{REFERENCES}

[1] El-Mougy, N.S., Aly, M.D.I.H., Embabi, E.I., Abdel-Kader, M.M., 2011, First Record of Sclerotinia Foliage Blight Disease on Pepper under Protected Cultivation System in Egypt. Proc. 12 $2^{\text {th }}$ Egyptian Phytopathological Society, 3-4 May, ARC, Cairo, Egypt

[2] Embabi, E.I., El-Mougy, N.S., Abdel-Kader, M.M., Lashin, S.M., 2011, First Record of Sclerotinia Blight Disease on Cucumber under Protected Cultivation System in Egypt. Proc. $12^{\text {th }}$ Egyptian Phytopathological Society, 3-4 May, ARC, Cairo, Egypt

[3] Jenny, J., 2000, Essential oils: A new idea for postharvest disease control, Good Fruit and Vegetables magazine, 11 (3), 50. Available online: http://postharvest.com.au/GFV_oils.P DF

[4] Stromberge, A., Brishammar, S., 1991, Induction of systemic resistance in potato (Solanum tuberosum L.) plants to late blight by local treatment with Phytophthora infestans, Phytophthora cryptogea or dipotassium phosphate, Potato Res., $34,219-225$

[5] Yurina, T.P., Karavaev, V.A., Solntsev, M.K., 1993, Characteristics of metabolism in two cucumber cultivars with different resistance to powdery mildew, Russian Plant Physiol., 40, 197-202

[6] Vaughan, D., Malcolm, R.E., Ord, B.G., 1985, Influence of humic substances on biochemical processes in plants In: Soil
Organic Matter and Biological Activity (Vaughan, D. and Malcolm, R.E., Eds.), pp. 78-108. Kluwer Academic Publishers, Dordrecht

[7] Visser, S.A., 1985, Effect of humic acids on numbers and activities of microorganisms within physiological groups, Org. Geochem., 8, 81-85

[8] Hoitank, H.A., Fahy, P.C., 1986, Basis for the control of soil borne plant pathogens with composts. Ann. Rev. phytopathol., $24,93-114$

[9] Zhang, W., Dick, W.A., Hoitink, H.A., 1996, Compost induced systemic acquired resistance in cucumber to Pythium root rot and anthracnose. Phytopathology, 83, 1066-1070

[10] Ferreira, J.H.S., Matthee, F.N., Thomas, A.C., 1991, Biological control of Eutypa lata on grapevine by an antagonistic strain of Bacillus subtilis. Phytopathology, 81, 283-287. doi: 10.1094/Phyto-81-283

[11] SAS, 1988, Statistical Analysis System. User's Guide: Statistics (PC-Dos 6.04). SAS Institute Inc., Cary, NC, USA

[12] Winer B.J. 1971. Statistical Principles in Experimental Design. $2^{\text {nd }}$ ed. MiGraw-Hil Kogakusha, LTD, 596 pp

[13] Ormancey, X., Sisalli, S., Coutiere, P., 2001, Formulation of essential oils in functional perfumery. Parfums, Cosmetiques, Actualites, 157, 30-40

[14] Karatzas, A.K., Bennik, M.H., Smid, E.J., Kets, E.P., 2000, Combined action of S-carvone and mild heat treatment on Listeria monocytogenes Scott A. J. Appl. Microbiol., 89, 296-301

[15] Simões, C.M.O., Schenckel, E.P., Gosman, G., Mello, J.C.P., Mentz, L.A., Perovick, P.R., 1999, Farmacognosia: da planta ao medicamento. Santa Catarina, Porto Alegre, Florianópolis: ed. da UFRGS; ed. da UFSC, p. 821

[16] Sagdiç, O., Karahan, A.G., Ozcan, M., Ozcan, G., 2003, Effect of some spices extracts on bacterial inhibition. Food Sci. Technol. Int., 9, 353-359

[17] Lanciotti, R., Gianotti, A., Patrignani, N., Belleti, N., Guerzoni, M.E., Gardini, F., 2004, Use of natural aroma compounds to improve shelf-life of minimally processed fruits. Trends Food Sci. Technol., 15, 201-208

[18] Karapinar, M., 1985, The effects of citrus oil and some Turkish spices on growth and aflatoxin production by Aspergillus parasiticus NRRL 2999. Int. J. Food Microbiol., 12, 239-245

[19] Nanir, S.P., Kadu, B.B., 1987, Effect of some medicinal plants extract on some fungi. Acta Botanica India, 15, $170-175$

[20] Nirmala Kishore Singh, S.K., Dubey, N.K., 1988, Fungitoxic activity of essential oil of Juniperus communis. Indian Perfunm., 33, 25-29

[21] Juglal, S., Govinden, R., Odhav, B., 2002, Spices oils for the control of co-occurring mycotoxin-producing fungi. J. Food Protect., 65, 638-687

[22] Reuveni, M.; Agapov, V., Reuveni, R., 1995a, Induced systemic protection to powdery mildew in cucumber by phosphate and potassium fertilizers, effects of inoculum concentration and post-inoculation treatment. Can. J. Plant Pathol, 


$$
17,247-251
$$

[23] Reuveni, M.; Agapov V., Reuveni, R., 1995b, Suppression of cucumber powdery mildew (Sphaerotheca fuliginea) by foliar sprays of phosphate and potassium salts. Plant Pathol., 44, 31-39

[24] Reuveni, M.; Agapov, V., Reuveni, R., 1996, Controlling powdery mildew caused by Sphaerotheca fuliginea in cucumber by foliar sprays of phosphate and potassium salts. Crop Protection, 15: 49-53

[25] Mosa, A.A. 1997. Effect of foliar application of phosphates on cucumber powdery mildew. Ann. Agric. Sci., 42: 241-255

[26] Abd-El-Kareem, F. 2007. Potassium or Sodium Bicarbonate in Combination with Nerol for Controlling Early Blight Disease of Potato Plants under Laboratory, Greenhouse and Field Conditions. Egypt. J. Phytopathol., 35: 73-86

[27] Mucharromah, E. and Kuc, J. 1991. Oxalate and phosphates induced systemic resistance against diseases caused by fungi, bacteria and viruses in cucumber. Crop Protection, 10: $265-270$

[28] Karabulut, O.A.; Bursa, G. and Mansour, M. 2003. Near -harvest applications of Metschnikowia fructicola, ethanol and sodium bicarbonate to control postharvest diseases of grape in central California. Plant Dis., 87: 1384-1389

[29] Smilanick, J.L.; Mansour, M.F. and Sorenson, D. 2006. Preand postharvest treatments to control green mould of citrus fruit during ethylene degreasing. Plant Dis., 90: 89-96

[30] Janisiewicz, W.J. and Peterson, D.L. 2005. Experimental Bin drenching system for testing biocontrol agents to control postharvest decay of apples. Plant Dis., 89: 487-490

[31] Saftner R.A., Conway W.S., Sams C.E. 1997. Effects of some polyamine biosynthesis inhibitors and calcium chloride on in vitro growth and decay development in apples caused by Botrytis cinerea and Penicillium expansum. J. Am. Soci. Horti. Sci. 122: 380-385

[32] El-Mougy, N.S.; El-Gamal, N.G. and Abd-Alla, M.A. 2008. The use of fungicide alternatives for controlling post harvest decay of strawberry and orange fruits. Journal of Plant Protection Research, 48 (3): 386-395

[33] Charest. M.H.; Chantal, J.B. and Antoun, H. 2005. Effects of the humic substances of de-inking paper sludge on the antagonism between two compost bacteria and Pythium ultimum.
FEMS Microbiology Ecology 52: 219-227

[34] El-Mohamedy, R.1 S.R. and Ahmed, M.A. 2009. Effect of Biofertilizers and Humic Acid on control of Dry Root Rot Disease and Improvement Yield Quality of Mandarin (Citrus reticulate Blanco). Research Journal of Agriculture and Biological Sciences, 5(2): 127-137

[35] Bodde T. 1982. Entomologists probe chemical defenses and natural enemies. Bio-science 32: 308-311

[36] Daoud A.S., Qasim N.A., Al-Mallah N.M. 1990. Comparison study on the effect of some plant extracts and pesticides on some phytopathogenic fungi. Mesopotamia J. Agric. 22: $227-235$

[37] Dwivedi S.K., Kishore N., Dwivedi S.K. 1990. Fungitoxicity of some essential oils against Macrophomina phaseolina. Indian Perfumer 34: 20-21

[38] Kumer A., Tripathi S.C. 1991. Evaluation of the leaf juice of some higher plants for their toxicity against soilborne pathogens. Plant Soil 132: 297-301

[39] Kim J., Marshall M.R., Wei C. 1995. Antibacterial activity of some essential oils components against five foodborne pathogens. J. Agric. Food Chem. 43: 2839-2845

[40] Lee S., Tsao R., Peterson C., Coats, J.R. 1997. Insecticidal activity of monoterpenoids to western corn rootworm (Coleoptera: Chrysomelidae), two spotted spider mite (Acari: Tetranychidae), and house fly (Diptera: Muscidae). J. Econ. Entomol. 90 (4): 883-892

[41] Wilson C.L., Solar J.M., El Ghaouth A., Wisniewski M.E. 1997. Rapid evaluation of plant extracts and essential oils for antifungal activity against Botrytis cinerea. Plant Dis. 81: 204-210

[42] Calvet C., Pinochet J., Camprubi A., Estaun V., Rodriguez -Kabana R. 2001. Evaluation of natural chemical compounds against root lesion and root-knot nematodes and side-effects on the infectivity of arbuscular mycorrhizal fungi. Eur. J. Plant Pathol., 107, 601-605

[43] Notermans S., Hoogenboon-Verdegaal A., 1992, Existing and emerging foodborne diseases. Int. J. Food Microbiol., 15, 197-205

[44] Cowan, M.M., 1999, Plant products as antimicrobial agents. Clinical Microbiol. Rev., 12, 564-582 